\title{
Variasi Warna Pipet pada Stik Perangkap Lalat terhadap Jumlah Lalat yang Tertangkap
}

\section{Straw Colour Variation of Fly Sticky Trap on Number of Catched Flies}

\author{
Iqbal Ardiansyah ${ }^{1 *}$, Bambang Wispriyono ${ }^{1}$, Indah Werdiningsih' ${ }^{2}$, Rizki Amalia ${ }^{2}$ \\ ${ }^{1}$ Departemen Kesehatan Lingkungan, Fakultas Kesehatan Masyarakat, Universitas Indonesia \\ ${ }^{2}$ Jurusan Kesehatan Lingkungan, Poltekkes Kemenkes Yogyakarta \\ (*iqbalardiansyah2694@gmail.com)
}

\begin{abstract}
ABSTRAK
Lalat merupakan vektor penyakit. Pada bagian tempat pemotongan ayam Pasar Gedebage memiliki kepadatan lalat tinggi 21 ekor/blok grill maka perlu adanya pengendalian salah satunya stik perangkap lalat. Tujuan penelitian untuk mengetahui pengaruh variasi warna pipet terhadap jumlah lalat yang tertangkap pada stik perangkap lalat dengan jenis penelitian kuasi eksperimen dan desain post test only design. Penelitian ini dilakukan di tempat pemotongan ayam HS Pasar Gedebage Bandung pada 25 sampai 30 Desember 2017 dengan subjek penelitian semua lalat yang berada di lokasi penelitian. Bahan dalam penelitian ini adalah pipet berwarna putih, kuning, merah dan biru. 3/4 permukaan pipet diolesi lem lalat beraroma durian. Metode dalam penelitian ini adalah penelitian kuantitatif, dianalisis secara deskriptif dan uji statistik. Uji statistik diawali uji normalitas Shaphiro wilk, lalu uji one way ANOVA dan Pos hoct test LSD. Hasil penelitian jumlah lalat terperangkap pada pipet putih rata-rata 32,6 ekor, pipet kuning rata-rata 24 ekor, pipet merah rata-rata 18 ekor dan pipet biru rata-rata 16 ekor. Hasil uji statistik nilai p-value 0,0005 menunjukan adanya perbedaan antara setiap warna pipet dengan jumlah lalat yang tertangkap, pipet putih merupakan warna pipet paling banyak memerangkap lalat. Kesimpulan penelitian warna pepet putih merupakan warna pipet terbaik untuk dijadikan stik perangkap lalat.
\end{abstract}

Kata kunci: Warna pipet, perangkap, lalat

\section{ABSTRACT}

Flies are vectors of disease. In the section of chicken slaughter, Pasar Gedebage has a high fly density of 21 tails / block grill hence it is necessary to control one of them fly sticky trap. The purpose of the study was to determine the effect of straw color variations on the number of flies caught in fly trap sticks with the type of quasi-experimental research and post-test only design. This research was conducted at HS Pasar Gedebage Bandung chicken slaughterhouse on 25 to 30 December 2017 with research subjects all flies were in the study location. The material in this study is white, yellow, red and blue straw. 3/4 straw surface smeared with durian flavored fly glue. The method in this study is quantitative research, analyzed descriptively and statistically tested. The statistical test begins with the normality test of Shaphiro Wilk, then tests on one way ANOVA and Post hoct LSD test. The results of the study were that the number of flies trapped in the white straw was 32,6 on average, the average yellow straw was 24, the red straw was on average 18 and the blue straw was 16 on average. Statistical test results p-value 0.0005 shows the difference between each color straw with the number of flies caught, the white straw is the color of the straw that traps the most flies. The conclusion research white color of straw is the best color straw for making fly sticky trap.

Keywords: Straw colour, trap, flies 


\section{PENDAHULUAN}

Sustainable Development Goals disingkat dengan SDGs adalah 17 tujuan dengan 169 capaian yang terukur dan tenggang waktu telah ditentukan oleh PBB sebagai agenda dunia untuk pembangunan kemaslahatan manusia dan planet bumi. Tujuan ke tiga SDGs yaitu kesehatan dan kesejahteraan yang baik, dengan cara mengakhiri epidemi AIDS, tuberkulosis, malaria dan penyakit tropis terabaikan dan memerangi hepatitis, penyakit yang terbawa air dan penyakit menular lainnya. ${ }^{1}$ Hal tersebut menjelaskan bahwa kesehatan dan kesejahteraan yang baik menjadi tujuan seluruh negara yang bergabung menjadi anggota PBB salah satunya Indonesia. ${ }^{1}$

Hal ini selaras dengan pembangunan kesehatan di Indonesia yang tercantum dalam UU Nomor 36 Tahun 2009, tentang kesehatan yaitu "meningkatkan kesadaran, kemauan dan kemampuan hidup sehat bagi setiap orang agar terwujud derajat kesehatan masyarakat yang setinggitingginya, sebagai investasi bagi pembangunan sumber daya manusia yang produktif secara sosial dan ekonomis. ${ }^{2}$ Salah satu penyelenggaraan kesehatan bagi masyarakat yaitu pengendalian terhadap vektor dan binatang pengganggu. Sebagaimana tercantum dalam PERMENKES Nomor 374 Tahun 2010 tentang pengendalian vektor, yang memiliki maksud dan tujuan untuk mencegah atau membasmi terjadinya penularan penyakit tular vektor di suatu wilayah, sehingga penyakit tersebut dapat dicegah dan dikendalikan. ${ }^{3}$

Menurut WHO secara global setiap tahun ada lebih dari 700.000 kematian akibat vector borne disesases. Penyakit-penyakit yang ditularkan melalui vektor utama salah satunya lalat, menyebabkan $17 \%$ dari semua penyakit menular. Secara tidak proporsional mempengaruhi populasi termiskin, menimpa populasi umum, merenggut nyawa dan membanjiri sistem kesehatan di banyak negara. Beban penyakit-penyakit ini paling tinggi di daerah tropis dan subtropik salah satunya Indonesia. ${ }^{4}$ Masalah kesehatan berkaitan dengan populasi lalat umumnya berhubungan dengan unit peternakan atau pemotongan hewan dan tempat pembuangan sampah domestik. Lalat merupakan jenis serangga yang mempunyai kemampuan terbang hingga jarak $8 \mathrm{~km}$ Dengan demikian tempattempat seperti pemukiman dalam daerah radius tersebut sangat rawan terhadap tingkat kepadatan lalat yang tinggi. ${ }^{5}$

Pasar Gedebage Bandung, merupakan pasar tradisional yang ada di kawasan Bandung Selatan. Pasar Gedebage merupakan sentral perekonomian bagi masyarakat Bandung Selatan, di Pasar Gedebage terdapat berbagai macam kebutuhan kehidupan manusia dari mulai sandang, pangan, dan papan. Pasar Gedebage kurang terawat khususnya di bagian tempat pemotongan ayam, sampah dari bulu ayam hasil pemotongan ayam hanya dibiarkan menumpuk di belakang tempat pemotongan ayam, yang berada di belakang tempat perbelanjaan pasar dimana kondisi lingkungan yang tidak sehat berisiko 4,2 kali memiliki kepadatan lalat lebih tinggi dibandingkan kondisi lingkungan yang sehat. ${ }^{6}$ Hasil survei yang dilakukan oleh peneliti dengan menghitung kepadatan lalat yaitu didapatkan hasil 21ekor/blok grill, angka tersebut menunjukan bahwa kepadatan lalat sangat tinggi, karena itu perlu adanya pengamanan pada tempat perkembangbiakan lalat dan dilakukan pengendalian lalat. ${ }^{5,7,8}$

Lalat diduga kuat menularkan setidaknya 65 penyakit kepada manusia, termasuk salmonellosis, diare, thypus, cholera, disentri, tuberculosis, dan trypanosomiasis. Lalat memuntahkan dan mengeluarkan ludah dimana pun mereka datang untuk beristirahat dan dengan demikian secara mekanis menularkan organisme penyakit. ${ }^{9-12}$ Lalat juga sering hinggap di tempat yang memanjang vertikal. ${ }^{13}$ Lalat memiliki dua tipe organ penglihatan utama yaitu mata tunggal frontal dan mata majemuk, bagian pada mata tunggal pada lalat berfungsi sebagai pembeda intensitas cahaya selain itu mata tunggal pada lalat juga berfungsi untuk merespon arah dan jarak dari sumber cahaya. Cahaya dapat dirasakan melalui warna-warna spectral tergantung dari panjang gelombangnya. Jika panjang gelombangnya $650 \mathrm{~nm}$ maka yang akan terlihat adalah warna merah lalu jingga, pada panjang gelombang $590 \mathrm{~nm}$, kuning $575 \mathrm{~nm}$, hijau $510 \mathrm{~nm}$, biru $475 \mathrm{~nm}$ dan ungu $470 \mathrm{~nm} .{ }^{14,15}$

Semua serangga memiliki penglihatan dan kepekaan terhadap warna. Pigmen-pigmen pada mata serangga memungkinkan penditeksian perbedaan panjang gelombang cahaya ataupun warna. ${ }^{8}, 16$ Ada beberapa serangga yang tampak buta warna, tetapi dapat membedakan warna con- 
tohnya adalah lebah dimana lebah dapat membedakan warna biru dan kuning namun tidak dapat melihat warna merah. ${ }^{17}$ Hal tersebut disebabkan adanya beberapa jenis serangga yang kekurangan atau tidak memiliki pigmen yang peka terhadap warna merah. ${ }^{18}$ Ekologi visual lalat luar biasa di antara serangga karena kombinasi atribut tertentu. ${ }^{19}$ Mata majemuk lalat memiliki rhabdom terbuka dan dengan demikian rhabdomeres terpisah di setiap ommatidium yang ditugaskan untuk dua jalur visual. Sistem superposisi saraf monovarian yang sangat sensitif didasarkan pada eksitasi rhabdomeres perifer dari sel retinula dan mengendalikan reaksi optomotor. Dua bentuk rhabdomer pusat sel retinula di setiap ommatidium membangun sistem dengan empat fotoreseptor yang sensitif dalam rentang panjang gelombang yang berbeda dan dianggap bertanggung jawab atas penglihatan warna. ${ }^{20}$ Dengan alasan tersebut peneliti melakukan penelitian mengenai variasi warna pipet pada stik perangkap lalat terhadap jumlah lalat yang tertangkap dengan variasi warna putih, kuning merah dan biru.

\section{BAHAN DAN METODE}

Metode dalam penelitian ini adalah penelitian kuantitatif dengan jenis penelitian yang digunakan adalah kuasi eksperimen dan desain penelitian post test only design. Penelitian ini dilakukan pada tanggal 25 sampai 30 Desember 2017 di tempat pemotongan ayam HS Pasar Gedebage, J1. Soekarno Hatta, Kelurahan Mekar Mulya, Kecamatan Panyileukan, Bandung. Subjek dalam penelitian ini adalah seluruh populasi lalat yang ada di tempat Pemotongan ayam HS khususnya di bagian penumpukan bulu ayam dengan teknik penyempe- lan total sampling dimana jumlah sempel sama dengan jumlah populasi. ${ }^{8,21,22}$ Stik perangkap lalat yang digunakan dibuat dengan bahan dan cara, pertama memanaskan lem tikus $100 \mathrm{ml}$ dengan bahan pengencer 2 sendok makan minyak goreng setelah lem mencair. Tambahkan esen atau pasta durian sebanyak 4 tetes, setelah lem jadi pindahkan ke toples kaca lalu dinginkan. Setelah dingin siapkan pipet dengan warna putih, kuning, biru dan merah, oleskan lem pada 3/4 permukaan pipet dan lapisi permukaan perangkap dengan plastik agar tidak saling menempel satu sama lain antara pipet satu dengan yang lainnya ketika dibawa ke lokasi penelitian..$^{11,23,24}$

Variabel bebas dalam penelitian ini adalah warna pipet pada stik perangkap lalat dan variabel terikatnya adalah jumlah lalat yang terperangkap pada stik perangkap lalat. ${ }^{25}$ Penelitian ini dilakukan dengan metode observasi, jalannya penelitian ini diawalali dengan pemasangan pipet dengan jarak yang sama antara pipet pada sumber berkumpulnya lalat, agar memiliki kemungkinan yang sama untuk dihinggapi lalat. Pengamatan dilakukan pada jam aktifnya lalat yaitu pada pukul 08.00 sampai 14.00 , setelah jam 14.00 perangkap pipet yang sudah dipasang diambil dan lakukan pengamatan serta penghitungan berapa jumlah lalat yang terperangkap pada stik perangkap lalat pada masing-masing warna. ${ }^{8,21,26-28}$ Penelitian ini dilakukan pengulangan sebanyak 6 kali pengulangan. ${ }^{29}$ Data yang diperoleh dari observasi dikelompokan dalam bentuk tabel kemudian dianalisis secara deskriptif dan dilanjutkan dengan uji statistik. Uji statistik diawali dengan melakukan uji normalitas data Shaphiro wilk, karena data yang didapatkan berdistribusi daengan normal kemudian dilanjut-

Tabel 1. Distribusi Lalat yang Terperangkap pada Stik Perangkap Lalat (Fly Sticky Tapes) dengan Variasi Warna Putih, Kuning, Biru dan Merah

\begin{tabular}{ccccccccc}
\hline \multirow{2}{*}{ Pengulangan } & \multicolumn{10}{c}{ Lalat yang Tertangkap } \\
\cline { 2 - 9 } & Putih & \% & Kuning & \% & Merah & \% & Biru & \% \\
\hline 1 & 35 & 38 & 25 & 27,2 & 17 & 18,5 & 15 & 16,3 \\
2 & 33 & 37 & 24 & 27 & 16 & 18 & 16 & 18 \\
3 & 32 & 34,5 & 23 & 24,7 & 20 & 21,5 & 18 & 19,3 \\
4 & 32 & 34,5 & 25 & 26,8 & 19 & 20,4 & 17 & 18,3 \\
5 & 34 & 37,8 & 22 & 24,4 & 18 & 20 & 16 & 17,8 \\
6 & 30 & 34,1 & 25 & 28,4 & 18 & 20,4 & 15 & 17.1 \\
\hline Jumlah & 196 & 36 & 36 & 26,4 & 108 & 19,8 & 97 & 17,8 \\
\hline Rata-Rata & 32.6 & 36 & 36 & 26,4 & 18 & 19,8 & 16,17 & 17,8 \\
\hline
\end{tabular}


Tabel 2. Hasil Uji Anova Lalat yang Terperangkap pada Stik Perangkap Lalat (Fly Sticky Tapes) dengan Variasi Warna Putih, Kuning, Biru dan Merah

\begin{tabular}{lcccc}
\hline \multicolumn{1}{c}{ Warna Pipet } & Mean & SD & P value & Keterangan \\
\hline Putih & 32.67 & 1,751 & 0,0005 & Ada Perbedaan Bermakna \\
Kuning & 24 & 1,265 & & \\
Merah & 18 & 1,414 & & \\
Biru & 16,17 & 1,169 & & \\
\hline
\end{tabular}

Tabel 3. Hasil Uji Post Hoct LSD Lalat yang Terperangkap Pada Stik Perangkap Lalat (Fly Sticky Tapes) Dengan Variasi Warna Putih, Kuning, Biru dan Merah

\begin{tabular}{lccc}
\hline \multicolumn{1}{c}{ Warna Pipet } & Sig & Mean Difference & Keterangan \\
\hline Putih - kuning & 0,0005 & 8,667 & Ada Perbedaan Bermakna \\
Putih - merah & 0.0005 & 14,667 & Ada Perbedaan Bermakna \\
Putih - biru & 0,0005 & 16,500 & Ada Perbedaan Bermakna \\
Kuning - Merah & 0,0005 & 6,000 & Ada Perbedaan Bermakna \\
Kuning - biru & 0,0005 & 7,833 & Ada Perbedaan Bermakna \\
Merah - Biru & 0,0450 & 1,833 & Ada Perbedaan Bermakna \\
\hline
\end{tabular}

kan dengan uji one way ANOVA dan Pos hoct test LSD (Least Signifian Different). ${ }^{30}$

\section{HASIL}

Jumlah lalat yang terperangkap pada stik perangkap lalat lebih banyak pada stik dengan pipet berwarna putih yaitu sebanyak 196 ekor dengan rata-rata 32,6 ekor atau sebesar $36 \%$ yang diikuti dengan stik perangkap lalat dengan warna pipet kuning dimana jumlah lalat yang terperangkap adalah sebanyak 144 ekor dengan rata-rata 24 ekor atau sebesar $26,4 \%$, pada pipet dengan warna merah jumlah lalat yang tertangkap sebanyak 108 ekor dengan rata-rata 18 ekor atau sebesar 19,8\% dan pada pipet dengan warna biru jumlah lalat yang terperangkap adalah 97 ekor dengan rata-rata 16 atau sebesar 17,8\% (Tabel 1).

Berdasarkan hasil uji statistik dengan uji anova diperoleh nilai p-value 0,0005 (p-value < $0,05)$ yang artinya terdapat perbedaan jumlah lalat yang tertangkap disetiap warna pipet yang berbeda (Tabel 2), dimana pipet berwana putih merupakan pipet yang paling efektif diantara semua variasi warna yang diuji dalam memerangkap lalat ditandai dengan mean different tertinggi yaitu 16,500 (Tabel 3).

\section{PEMBAHASAN}

Pemasangan stik perangkap lalat adalah suatu upaya dalam pengendalian kepadatan nyamuk yang menggabungkan metode secara fisik melalui warna pipet yang digunakan dan kimia melalui lem perekat dan bau dari antraktan.,31-33 Lokasi dan kondisi tempat pemotongan ayam HS yang dekat dengan pemukiman dan tidak terkelola baik sangat berpotensi menjadi sarang atau tempat perkembangbiakan lalat dimana lalat merupakan jenis serangga yang mempunyai kemampuan terbang hingga jarak $8 \mathrm{~km}$, dengan demikian tempattempat seperti pemukiman dalam daerah radius tersebut sangat rawan. ${ }^{5}$

Hasil penelitian ini menunjukan kesamaan dengan penelitian sebelumnya bahwa ada perbedaan jumlah lalat yang tertangkap pada setiap variasi warna digunakan pada perangkap lalat namun ada beberapa perbedaan warna yang dominan dalam mempengaruhi banyaknya lalat yang tertangkap. Seperti yang dilakukan Sayono yang meneliti variasi warna pada tali di impregnated cord terhadap jumlah lalat yang tertangkap dengan hasil rerata lalat yang terperangkap pada tali yang berwarna kuning memiliki angka paling tinggi yaitu 46,963 ekor lalu putih 34,852 dan pada warna biru reratanya sebesar 14,815 . Setelah itu Sayono, et al melakukan kembali penelitian dengan jenis perangkap, perangkap kertas yang dibedakan variasi warnanya dengan hasil kertas berwarna putih mampu menangkap lalat lebih banyak dengan rerata 5,25, disusul denga warna kuning denga rerata 4,8 , hijau dengan rerata 2,0 dan biru dengan rera- 
ta 2,0. Robertus, et al juga melakukan penelitian serupa dengan menggunakan variasi warna lampu dengan warna biru, ungu dan hijau pada perangkap lalat terhadap jumlah lalat yang tertangkap dengan hasil pada lampu berwarna biru memiliki rata-rata tertinggi dalam menangkap lalat yaitu sebanyak 30 ekor, lalu ungu dengan 24 ekor dan terakhr warna hijau dengan rata-rata 15 ekor. Penelitian yang dilakukan oleh Silva, et al di Brazil dengan penggunaan Light-Emitting Diode (LED) variasi warna hijau biru dan lampu pijar biasa sebagai kontrol dengan hasil lampu LED hijau adalah yang paling menarik, diikuti oleh lampu biru dan pijar, dan perbedaan antara LED hijau dan kontrolnya signifikan secara statistik. ${ }^{21,26,27,34}$

Sebagian besar lalat yang tertangkap adalah jenis lalat hijau chrysomya dengan ciri-ciri berukuran besar mempunyai mata merah besar dan memiliki warna tubuh hijau metalik dan sebagian lagi yaitu jenis lalat daging sarcophaga dengan ciri-ciri berwarna abu-abu tua, berukuran sedang. Lalat ini mempunyai garis gelap pada bagian punggung dan perutnya mempunyai corak seperti papan catur. Hal tersebut dimungkinkan karena peneliti melakukan penelitian di tempat dengan habitat yang cocok bagi jenis lalat tersebut dimana kedua lalat tersebut sering hinggap pada kotoran bangkai atau daging. Selain itu warna putih dan kuning merupakan warna yang mirip dengan makanan dengan jenis lalat tersebut seperti daging. ${ }^{12,35}$ Lalat hijau atau chrysomya berkembang biak di bahan yang cair atau semi cair yang berasal dari hewan, termasuk daging, ikan, daging busuk, bangkai, sampah penyembelihan, sampah ikan, sampah dan tanah yang mengandung kotoran hewan. Lalat ini jarang berkembang biak di tempat kering atau bahan buah-buahan. Beberapa jenis juga berkembang biak di tinja dan sampah hewan dan yang lainnya bertelur pada luka hewan dan manusia. Lalat daging sarcophaga umum ditemukan di pasar dan warung terbuka, pada daging, sampah dan kotoran, tetapi jarang memasuki rumah. ${ }^{8}$ Jenis lalat tersebut dapat menularkan berbagai macam penyakit salah satunya salmonellosis, diare, thypus, cholera, disentri, tuberculosis, dan trypanosomiasis. ${ }^{9-12}$

\section{KESIMPULAN DAN SARAN}

Kesimpulan pada penelitian ini adalah ada perbedaan jumlah lalat yang terperangkap pada variasi pipet warna putih, kuning, biru dan merah. Pipet putih merupakan warna pipet yang paling baik untuk digunakan sebagai stik perangkap lalat. Saran untuk warga atau pemilik tempat pemotongan ayam perlu adanya pengendalian lalat untuk mengendalikan populasi lalat di tempat pemotongan ayam HS di Pasar Gedebage Bandung untuk menjaga para pekerja bahkan pemilik tempat pemotongan ayam dari penyakit yang dapat ditularkan oleh lalat tersebut. Bukan hanya di tempat pemotongan ayam tetapi dapat dilakukan juga di bagian pasar lain atau di tempat umum lainnya yang memiliki kepadatan lalat tinggi dan berpotensi menjadi tempat terjadinya penularan penyakit yang ditularkan lalat. Pipet berwarna putih merupakan pipet yang dianjurkan untuk digunakan dan dapat diaplikasikan sebagai stik perangkap lalat yang dapat dipasang di tempat-tempat yang diduga menjadi tempat berkumpulnya lalat yang diharapkan dapat menurunkan kepadatan lalat dan menurunkan risiko terjadinya penularan penyakit yang ditularkan lalat. Untuk peneliti lain dapat melakukan penelitian serupa dengan jenis alat perangkap yang berbeda.

\section{DAFTAR PUSTAKA}

1. United Nation. Transforming Our Word: the 2030 Agenda for Sustainable Development. New York: Department of Economic and Social Affairs United Nation; 2015.

2. Kementrian Kesehatan RI. UU No 36 Tahun 2009 Tentang Kesehatan. Jakarta: Kementerian Kesehatan RI; 2009.

3. Kementrian Kesehatan RI. PERMENKES No 374 Tentang Pengendalian Vektor. Jakarta: Kementerian Kesehatan RI; 2010.

4. World Health Organization. Vector-Borne Diseases [Online], 2017 [diakses pada 20 Juli 2019]. Available at: https://www. who.int/news-room/fact-sheets/detail/vector-borne-diseases.

5. Puspitarani F, Sukendra DM, Siwiendrayanti A. Penerapan Lampu Ultraviolet pada Alat Perangkap Lalat terhadap Jumlah Lalat Rumah Terperangkap. HIGEIA Journal of Public Health Research and Development. 2017; 1(3):151-161.

6. Afrilia EN, Bambang Wispriyono. Hubu- 
ngan Kondisi Rumah dan Kepadatan Lalat di Sekitar Tempat Pembuangan Akhir Sampah. Jurnal Fakultas Kesehatan Masyarakat. 2017; 11(2):99-104.

7. Ditjen PPPL. Pedoman Pengendalian Lalat. Jakarta: Kementerian Kesehatan RI; 2014.

8. Fajriansyah. Efektivitas Penggunaan Perekat Lalat dan Umpan Lalat Dalam Pengendalian Lalat Rumah. AcTion Journal. 2016;1(1).

9. Baldacchino F, Muenworn V, Desquesnes M, et al. Transmission of Pathogens by Stomoxys Flies (Diptera, Muscidae): a Review. Parasite. 2013;20(26):1-13.

10. Sucipto CD. Vektor Penyakit Tropis. Yogyakarta: Gosyen Publishing; 2011.

11. Sigit SH, Koesharto F, Hadi UK, et al. Hama Permukiman Indonesia: Pengenalan, Biologi, dan Pengendalian. Bogor: Unit Kajian Pengendalian Hama Permukiman, Fakultas Kedokteran Hewan, Institut Pertanian Bogor; 2006.

12. Jacobs SB. House Flies. Pennsylvania: Dept. of Entomology The Pennsylvania State University; 2013.

13. Suyono, Budiman. Ilmu Kesehatan Masyarakat dalam Konteks Kesehatan Lingkungan. Jakarta: EGC; 2011.

14. Cromer, H A. Fisika untuk Ilmu-Ilmu Hayati. Yogyakarta: Gadjah Mada University Press; 1994.

15. Sobel MI. Light. Chicago: University of Chicago Pres; 1987.

16. Gullan PJ, Cranston PS. The Insects an Outline of Entomology. Oxford: John Wiley \& Sons Ltd; 2010.

17. Borror DJ, Triplehorn CA, Johnson NF. Introduction to the Study of Insects. 6th ed. New York: Saunders College Pub; 1989.

18. SchmidtK,Nielsen. AnimalPhysiology:Adaptation and Environment. New York: Cambridge University Press; 1997.

19. Fernández MS, Martínez MF, Pérez AA, et al. Performance of Light-Emitting Diode Traps for Collecting Sand Flies in Entomological Surveys in Argentina. Journal of Vector Ecology. 2015;40(2):373-378.

20. Lunau K. Visual Ecology of Flies with Particular Reference to Colour Vision and Colour Preferences. Journal of Comparative Physio- logy A. 2014;200(2): 497-512.

21. Prasetya RD, Yamtana, Amalia R. Pengaruh Variasi Warna Lampu Pada Alat Perekat Lalat Terhadap Jumlah Lalat Rumah (Musca Domestica) yang Terperangkap. BALABA. 2015;11(1):29-34.

22. Alten B, Ozbel Y, Ergunay K, et al. Sampling Strategies for Phlebotomine Sand Flies (Diptera: Psychodidae) in Europe. Bulletin of Entomological Research 2015;105(6):664-678.

23. Schutze MK, Cribb BW, Cunningham JP, et al. 'Ladd Traps' as a Visual Trap for Male and Female Queensland Fruit Fly, Bactrocera Tryoni (Diptera: Tephritidae). Austral Entomology. 2016;55(3):324-329.

24. M. T, S L, U H, et al. Addition of Synthetic Feeding Attractant Increases Catches of Rhagoletis Batava Hering and Carpomyia schineri Loew in Fluorescent Yellow Sticky Traps. Acta Phytopathologica et Entomological Hungarica. 2016;51(1):69-76.

25. Notoatmodjo S. Metodologi Penelitian Kesehatan. Jakarta: Rineka Cipta; 2012.

26. Sayono. Pengaruh Posisi dan Warna Impregnated Cord terhadap Jumlah Lalat yang Tertangkap. UNIMUS; 2004.

27. Sayono, Mardhotiltah S, Martini. Pengaruh Aroma Umpan dan Warna Kertas Perangkap terhadap Jumlah Lalat yang Terperangkap. LITBANG Universitas Muhammadiyah Semarang 2005;2(2):30-36.

28. Kaba D, Zacarie T, M'Pondi AM, et al. Standardising Visual Control Devices for Tsetse Flies: Central and West African Species Glossina Palpalis Palpalis. PLOS Neglected Tropical Diseases. 2014;8(1):1-11.

29. Hanafiah KA. Rancangan Percobaan: Teori \& Aplikasi. 3th ed. Jakarta: Rajawali Pers; 2014.

30. Hastono SP, Sabri L. Statistik Kesehatan. Jakarta: Rajawali Pers; 2010.

31. C.Dominiak B, Wiseman B, Anderson C, et al. Definition of and Management Strategies for Areas of Low Pest Prevalence for Queensland Fruit Fly Bactrocera Tryoni Froggatt. Crop Protection. 2015;72(June): 41-46.

32. Santer RD. A Colour Opponent Model That Explains Tsetse Fly Attraction to Visual Baits 
and Can Be Used to Investigate More Efficacious Bait Materials. PLOS Neglected Tropical Diseases. 2014;8(12):1-16.

33. Yee WL. Commercial Yellow Sticky Strips more Attractive than Yellow Boards to Western Cherry Fruit Fly (Dipt., Tephritidae). Journal of Applied Entomology. 2015;139(4): 289-301.

34. Silva FS, Silva AA da, Rebêlo JMM. An Evaluation of Light-Emitting Diode (LED)
Traps at Capturing Phlebotomine Sand Flies (Diptera: Psychodidae) in a Livestock Area in Brazil. Journal of Medical Entomology. 2016;53(3):634-638.

35. Jürgens A, Witt T, Sciligo A, et al. The Effect of Trap Colour and Trap-Flower Distance on Prey and Pollinator Capture in Carnivorous Drosera Species. Functional Ecology. 2015; 29:1026-1037. 